\title{
Dynamic spillovers between stock and money markets in Nigeria: A VARMA-GARCH approach
}

\author{
AFEES A. SALISU \\ University of Ibadan, Nigeria* \\ KAZEEM O. ISAH \\ University of Ibadan and Kogi State University (KSU), Nigeria
}

\author{
ALBERTO ASSANDRI \\ Independent Researcher, Italy
}

\begin{abstract}
This study examines probable dynamic spillover transmissions between the Nigerian stock and money markets using the multivariate volatility framework that simultaneously accounts for both returns and shock spillovers. Based on relevant pre-tests, the VARMACCC-GARCH framework is selected and consequently employed to model the spillovers. The study finds significant cross-market return and shock spillovers between the two markets. Thus, a shock to one market is more likely to spill over to the other market. It is also observed that shocks have persistent effects on stock market volatility but transitory effects on money market volatility. In other words, shocks to the money market die out over time while shocks to stock market tend to persist over time. In addition, including lagged own shocks and lagged own conditional variance when forecasting the future volatility of both return series may enhance their forecast performance. An alternative approach proposed by Diebold and Yilmaz (2012) is also employed for robustness and the results are consistent with those obtained from the VARMA-CCC-GARCH model.
\end{abstract}

Keywords: Return Spillover, Shock Spillover, Shork Persistence, VARMA-CCCGARCH

JEL Classifications: C58, G10

\footnotetext{
Salisu: Centre for Econometric and Allied Research (CEAR), University of Ibadan, Nigeria, aa.salisu@cear.org.ng, adebare1@yahoo.com; Kazeem O. Isah: Centre for Econometric and Allied Research (CEAR), University of Ibadan, Nigeria and Department of Economics, Kogi State University (KSU), Anyigba, Kogi State, kzamboja@yahoo.com; Alberto Assandri: alberto.assandri@hotmail.com.

(C) 2019 Afees A. Salisu, Kazeem O. Isah, Alberto Assandri. Licensed under the Creative Commons Attribution - Noncommercial 3.0 Licence (http: / / creativecommons.org/Iicenses/by$\mathrm{nc} / 3.0 /$. Available at http://rofea.org.
} 


\section{Introduction}

Portfolio diversification has become a veritable investment strategy for mitigating the unpredictability of markets for investors. It helps to reduce portfolio loss and volatility particularly during periods of increased uncertainty. Perhaps due to its significance, studies dealing with spillover effects in financial markets are quite huge. Interestingly, the analyses appear to have covered the different layers of financial markets (i.e. developed, emerging and under-developed financial markets) (see for a review of the relevant literature, Salisu and Oloko, 2015a\&b; Kang and Yoon, 2017; Kang et al., 2017). Despite the impressive contributions rendered in the literature on spillover analyses; very limited studies are available on African financial markets. The few notable studies on Africa are Duncan and Kabundi (2013), Giovannetti and Velucchi (2013), Kuttu (2014, 2017), Sugimoto et al. (2014), King and Botha (2015), Oberholzer and Boetticher (2015), Fowowe and Shuaibu (2016) and Kambouroudis (2016). The only prominent reason often adduced is the fact that most financial markets in Africa are under-developed, less integrated and independent to each other and by implication; they are less vulnerable to external shocks.

In the wake of the $21^{\text {st }}$ century however and more noticeably after the global financial crisis, the reversal of this trend gradually began to emerge. Giovannetti and Velucchi (2013) comprehensively document these new trends about African financial markets. For instance, the Economist characterised Africa as the final frontier of globalisation for international investors (29/7/07), suggesting to "Buy Africa"' (19/2/2008) to diversify their risk (see also Giovannetti and Velucchi, 2013). Many African markets have been found to offer very large returns to investors and ever since 1995, there has been at least one African stock market in the top 10 best-performing markets in the world every year since 1995 (Giovannetti and Velucchi, 2013). In 2004, for example, six African countries (Ghana, Uganda, Kenya, Egypt, Mauritius and Nigeria) were among the world's 10 best-performing stock markets, while in 2005, Egypt, Uganda and Zambia were in the top five (Giovannetti and Velucchi, 2013).

In addition to the scarce literature on Africa, one thing that is also conspicuously scanty in the literature is country specific analysis. Most of the studies in the literature essentially focus on inter-country financial market spillovers which account for spillovers across countries/international financial markets. Of course, the outcome of such analyses offers useful insights to foreign portfolio investors/managers on how to diversify their asset base in the international financial markets. ${ }^{1}$ However, domestic investors within a country would also require information on how to diversify their assets within the domestic financial market.

${ }^{1}$ In fact, most of these studies on international financial markets centre on stock/equity market spillovers; very limited papers are available on spillovers among different financial markets simultaneously such as equity, bond, currency and money markets. See table 1 for a cursory review of relevant studies. 


\section{SALISU, ISAH ASSANDRI Dynamic Spillovers in Nigeria}

Such information can only be teased out from intra-country financial spillovers; that is, spillovers among financial assets within the same domestic economy. The only few recent studies dealing with intra-country spillovers are Dean et al. (2010) focusing on Australia; Karmakar (2010) on India; Raimony and El-Nader (2012) on Jordan; Diebold and Yilmaz (2012), Weber (2013), and Cronin (2014) focusing on US; Duncan and Kabundi (2013) on South Africa; Kanga et al. (2013) on Korea; and Wahyudi and Sani (2013) on Indonesia.

On the basis of these limitations in the literature, our paper focuses on intra-country spillovers drawing evidence from Nigeria. Some of the attractions to Nigeria are highlighted as follows. Nigeria has one of the largest pools of investment capital in Africa, with approximately five million registered capital market investors (KPMG report, 18/05/2015). In addition, the Nigerian financial markets service the largest economy in sub-Saharan Africa (KPMG report, 18/05/2015) and therefore, the database is more likely to provide very rich information about the dynamic behaviour of investors as well as the managers of the financial institutions.

Specifically, we analyse spillovers between two prominent financial markets in Nigeria, namely; the money market and the stock market. Apparently, most studies on financial spillovers majorly involve the capital market (debt and equity) and currency market while the money market is rarely included in the asset classes studied. The few recent studies including money market in their spillover analyses are Browne and Cronin (2010,2012), Wahyudi and Sani (2013), Cronin (2014) and Nguyen and Nguyen (2014). Two conflicting positions are rendered by Friedman (1988) regarding the nature of relationship between the money market and the stock market. These two positions are christened as the "wealth effect" and the "substitution effect". The wealth effect assumes a positive relationship between stock prices and money - that is, a fall in stock prices reduces demand for money. However, the substitution effect assumes a negative relationship between the two variables in that a fall in the return in equities will lead to a substitution of stocks for money. Although Friedman's empirical evidence supports the wealth effect; he, however, submits that which factor dominates the other is an empirical issue (see Cronin, 2014).

In addition to the above considerations, we also conduct a survey of prominent studies on spillovers ranging from the choice of financial markets, methodological approaches, data utilized to their empirical findings (see Tables 1A and 1B). This we believe would facilitate the comprehension of the extant literature as well as areas of further research. Our paper is structured as follows: Section 2 presents the literature review; Section 3 describes the data and also provides some preliminary analyses; Section 4 presents the model with the underlying assumptions; Section 5 presents and discusses the results with diagnostics; while Section 6 concludes the paper. 


\section{Literature Review}

In the finance literature, studies on volatility spillovers can be classified into two broad strands. The first strand relates to studies dealing with spillovers for a single market irrespective of the number of countries involved (i.e. whether within a country or across countries). We may classify this strand as single-market spillovers. The second strand covers studies that engage different financial markets and this may be named multiple-market spillovers.

Studies involving single-market spillovers are rapidly growing with the extant literature concentrating on volatility transmission in stock markets. The distinctions among these studies however lie in their choice of countries and methodological approaches. Majority of them cover international stock markets involving a combination of two or more countries drawn from the US, UK, Europe, Gulf Cooperation Council (GCC) countries to Asia while a small number of them engage in individual country analyses. For example, Kim and Rogers (1994) focus on stock markets in Korea, Japan and the US and the symmetric GARCH $(1,1)$ model was employed while Koutmos (1995) focus on the US, Japan and UK stock markets using the asymmetric GARCH (EGARCH) model. Using the same model as the latter, Booth et al. (1997) cover selected Scandinavian stock markets. Notwithstanding the depth of work on stock market spillovers, the stock markets in the US, Europe and Asia have dominated the literature. Although very few, there is also evidence of studies looking at single-market spillovers other than stock market. The few studies are Skintzi and Refenes (2006) using European and US Bond Markets, and Antonakakis and Vergos (2013), Claeys and Vašicek (2014) and Fernández-Rodríguez et al. (2015) using sovereign bond markets in Europe.

Similarly, there is a plethora of studies involving two or more financial markets such as the bond, currency, money, and stock markets regardless of whether the analysis is country specific or across countries. For example, Steeley (2006), Dean et al. (2010), Zhang et al. (2013) and Cenedese and Mallucci (2015) cover two markets namely bond and equity markets. Another prominent combination of two financial assets evident in the literature involves equity and money markets (see for example, Browne and Cronin, 2012; Wahyudi and Sani, 2013; and Cronin, 2014). Also studies like Flemming et al. (1998) and Nguyen and Nguyen (2014) have analysed spillovers among three financial markets relating to bond, equity and money markets while Kal et al. (2015) deal with bond, currency and equity markets. Analyses of four financial markets involving bond, commodity, currency, and equity markets have also been documented in the literature; the only notable study in this regard is Diebold and Yilmaz (2012) while Liow (2015) extends the work of the latter to include real estate. Also, in terms of modelling, the prominent models used in the literature are the Diebold and Yilmaz $(2009,2012)$ models and the multivariate GARCH models such as the CCC, DCC, BEKK and the Ling and McAleer (2003) VAR-GARCH and VARMA-GARCH including their asymmetric versions. 


\section{SALISU, ISAH ASSANDRI Dynamic Spillovers in Nigeria}

As previously noted, studies dealing with spillovers in African financial markets are scarce and with the renewed interest by foreign portfolio managers to invest in Africa owing to the impressive performance of some financial markets after the global financial crisis; it, therefore, becomes imperative to begin to conduct research that will offer useful information to both local and international profit maximizing investors.

\section{Data Description and Preliminary Analysis}

Essentially, this study covers two variables namely the stock market and the money market with the former proxied by All Share Index (ASI) of the Nigerian Stock Exchange while the latter is captured by the government bond yield (i.e. Treasury Bills). The ASI covers all the listed equities on the Exchange, including those listed on the Alternative Securities Market (ASeM), regardless of capitalization. The treasury bills (T-bills) used here is the short term (3-month) T-bills. The long term (6-month) T-bills is not considered due to data paucity; the publication of the data only commenced in 2008. The variables are sourced from the Central Bank of Nigeria's Statistical bulletin over the monthly period of January 2000 to September 2015. The graphical representation of the two series is shown in Figure 1.

Figure 1: Relationship between Stock Market and Money Market in Nigeria, 2000:M1-2015:M7

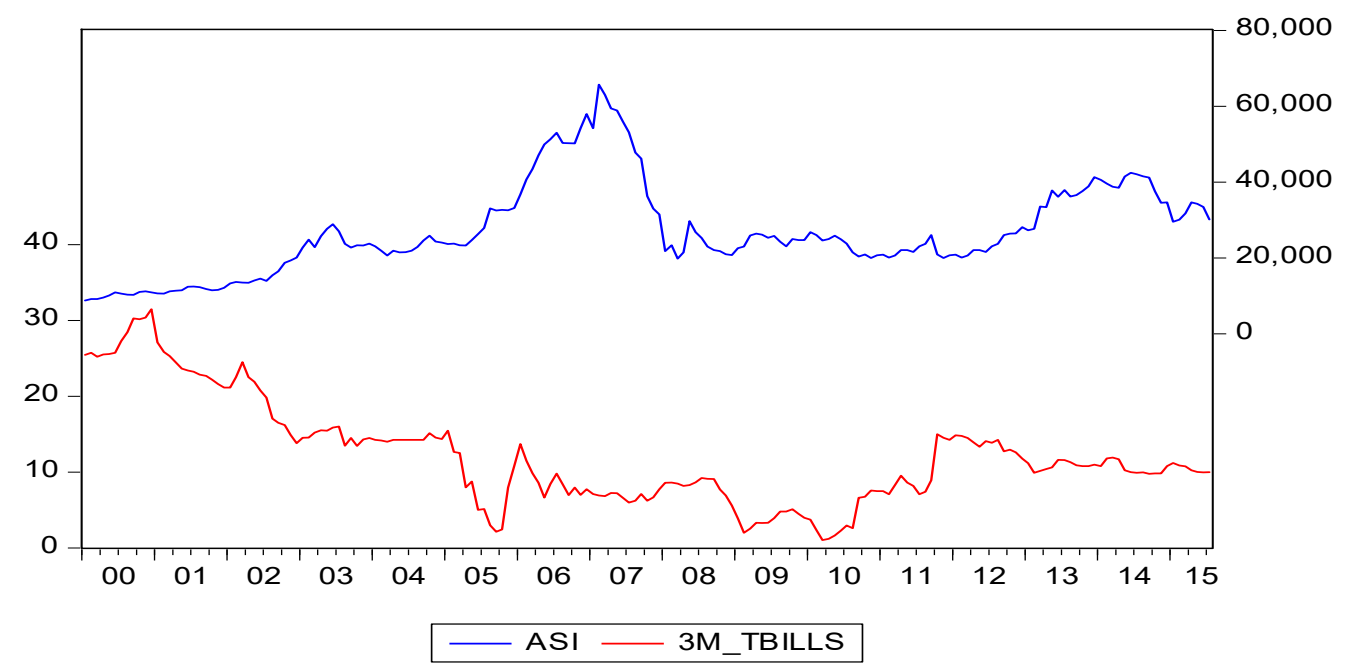

The graph appears to suggest a negative correlation between stock price index and the treasury bills. Nonetheless, our interest however is to evaluate the dynamic spillover effects between the returns of the two series. This is not unconnected with the fact that profit maximizing investors consciously follow trends in returns rather than the level series when 
making investment decisions. Thus, we use the continuously compounded returns for both markets as computed below:

$$
\begin{array}{r}
\text { Stock index return }(\text { stock })=\ln \left(\operatorname{asi}_{\mathrm{t}+1} / \operatorname{asi}_{\mathrm{t}}\right) \\
\text { Money market return }(\text { money })=\ln (1+\mathrm{T} \text {-bills })
\end{array}
$$

The descriptive statistics for the returns covering the mean, median, standard deviation as well as correlation are presented in Table 1 . The mean of the summary statistics indicates that average returns in money market exceed that of stock market. The standard deviation on the other hand, reveals that volatility in the stock market exceeds that of the money market. More so, the median money market is extremely larger than the median for the money market returns. However, stock market and money are shown to be weakly correlated.

Furthermore, we explore some potential interdependencies in stock and money market returns conditioned on the signs of the returns in stock market. We find the volatility of money market returns to be higher than that of stock irrespective of the signs of the latter. However, the correlation suggests that both returns are negatively correlated when the stock is positive and positively correlated when the stock is negative.

Table 1: Descriptive Statistics for Stock and Money Market Returns for both Conditional \& Unconditional Statistics

\begin{tabular}{|c||c|c|c|c|c|c|c|c|}
\hline \multicolumn{1}{|c||}{} & \multicolumn{2}{c|}{ Mean } & \multicolumn{2}{c|}{$\begin{array}{c}\text { Standard } \\
\text { Deviation }\end{array}$} & \multicolumn{2}{c|}{ Median } & Corr. & \multirow{N}{*}{ N } \\
\cline { 2 - 8 } & $\begin{array}{c}\text { Stock } \\
\text { market }\end{array}$ & $\begin{array}{c}\text { Money } \\
\text { market }\end{array}$ & $\begin{array}{c}\text { Stock } \\
\text { market }\end{array}$ & $\begin{array}{c}\text { Money } \\
\text { market }\end{array}$ & $\begin{array}{c}\text { Stock } \\
\text { market }\end{array}$ & $\begin{array}{c}\text { Money } \\
\text { market }\end{array}$ & & \\
\hline \hline Unconditional & 0.663 & 11.314 & 7.362 & 5.941 & 0.302 & 10.256 & 0.08 & 188 \\
\hline Stock>0 & 5.518 & 11.672 & 4.858 & 5.788 & 4.606 & 10.876 & -0.107 & 100 \\
\hline Stock<0 & -4.862 & 10.777 & 5.63 & 6.018 & -3.487 & 9.421 & 0.173 & 88 \\
\hline
\end{tabular}

Note: $\mathrm{N}$ is the number of observations. Unlike Dean et al (2010) with four possible conditional scenarios, we have two as shown in the table since the money market return is positive all-through the data period. Nonetheless, we are able to evaluate any possible variation in the relevant statistics given these scenarios.

In addition, we conduct formal tests to evaluate the statistical features of the series in order to justify the consideration of volatility models for the spillover analyses. The results of these tests are shown in Table 2. As expected for financial series, the distributions for both return series are skewed and leptokurtic. In other words, the distributions of both money and stock (whether right- or left-tailed) are heavier than normal and therefore, the normal distribution 


\section{SALISU, ISAH ASSANDRI Dynamic Spillovers in Nigeria}

assumption is inappropriate for the analysis of their spillover effects. Also, using the LjungBox test for serial correlation, we find evidence for the presence of significant higher order serial dependencies in both series. Similarly, the presence of ARCH effects is also evident in both series based on the Engle (1982) LM tests for ARCH.

Table 2(a): Some formal pre-tests for Stock and Money Market Returns

\begin{tabular}{|l|c|c|}
\hline Statistics & $\begin{array}{c}\text { Stock } \\
\text { market }\end{array}$ & $\begin{array}{c}\text { Money } \\
\text { market }\end{array}$ \\
\hline \hline Skewness & -0.485 & 0.715 \\
\hline Kurtosis & 8.116 & 3.019 \\
\hline Jarque-Bera normality test & $210.125^{\mathrm{a}}$ & $15.916^{\mathrm{a}}$ \\
\hline $\mathrm{LB}(5)$ returns & $13.004^{\mathrm{a}}$ & $781.155^{\mathrm{a}}$ \\
\hline $\mathrm{LB}(10)$ returns & $17.931^{\mathrm{a}}$ & $1331.703^{\mathrm{a}}$ \\
\hline $\mathrm{LB}(5)$ squared returns & $30.718^{\mathrm{a}}$ & $799.019^{\mathrm{a}}$ \\
\hline $\mathrm{LB}(10)$ squared returns & $34.141^{\mathrm{a}}$ & $1357.498^{\mathrm{a}}$ \\
\hline $\mathrm{ARCH}-\mathrm{LM}(5)$ test & $27.259^{\mathrm{a}}$ & $177.009^{\mathrm{a}}$ \\
\hline $\mathrm{ARCH}-\mathrm{LM}(10)$ test & $30.019^{\mathrm{a}}$ & $171.561^{\mathrm{a}}$ \\
\hline
\end{tabular}

Table 2(b): Post estimation/Diagnostic test on VAR model

\begin{tabular}{|l|c|c|}
\hline Model & ARCH-LM & ARCH-LM \\
\cline { 2 - 3 } & $\begin{array}{c}\text { (without } \\
\text { cross term) }\end{array}$ & $\begin{array}{c}\text { (with cross } \\
\text { term) }\end{array}$ \\
\hline \hline $\operatorname{VAR}(2)$ & $55.754^{\mathrm{a}}$ & $68.886^{\mathrm{a}}$ \\
\hline $\operatorname{VAR}(5)$ & $125.713^{\mathrm{a}}$ & $348.580^{\mathrm{a}}$ \\
\hline $\operatorname{VAR}(10)$ & $165.150^{\mathrm{a}}$ & $514.453^{\mathrm{a}}$ \\
\hline
\end{tabular}

Note: ${ }^{a}$ denotes statistical significance at $5 \%$ level. The values in parentheses represent the lag orders for the relevant tests and models in the case of post-estimation tests. The LB is the Ljung-Box test for autocorrelation while the ARCH-LM test is the Engle (1982) test for ARCH effects.

There is no gain saying that the various pre-tests results in Table 2(a) has further strengthened our choice of volatility -based multivariate modelling framework in this study. But for the sake of robustness and consistence, we yet take a pause to examine the appropriateness or otherwise of conventional multivariate approach to modelling shock transmission using for instance, (VAR) models. Reported in 2(b) is post -estimation results obtained from the diagnostic tests performed on the various orders of VAR models considered. The results which yet indicate significant evidence of $\mathrm{ARCH}$ effect tend to reaffirms the validity of our 
preferred volatility -based multivariate model as the more appropriate given the statistical feature of the data under consideration.

Consequently, it has become increasingly important in the literature to account for asymmetry effect when modelling the behaviour of financial series (see for example, Dean et al, 2010 and Salisu and Oloko, 2015a\&b). This idea became popular after the seminal paper of Nelson (1991) arguing that positive and negative shocks of the same magnitude may not give identical impacts on the conditional variance. However, rather than modelling the asymmetry directly in the model; Engle and $\mathrm{Ng}$ (1993) propose three pre-tests: the sign bias test, the negative size bias test and the positive size bias test to verify the presence of asymmetry effect. The logic of the tests is to see whether having estimated a particular GARCH model, an asymmetry dummy variable is significant in predicting the squared residuals (Harris and Sollis, 2003). The tests are of the null hypothesis that the null model is correctly specified suggesting that there is no remaining asymmetry (Harris and Sollis, 2003). These sign and size bias tests are individually computed using the following regressions:

$$
\begin{array}{ll}
\text { Sign bias test: } & v_{t}^{2}=a+b S_{t-1}^{-}+e_{t} \\
\text { Negative size bias test: } & v_{t}^{2}=a+b S_{t-1}^{-} u_{t-1}+e_{t} \\
\text { Positive size bias test: } & v_{t}^{2}=a+b S_{t-1}^{+} u_{t-1}+e_{t}
\end{array}
$$

where $u_{t}$ is the error term under the null, $S_{t-1}^{-}$is a dummy variable that takes the value of one when $u_{t-1}<0$ and zero otherwise (vice versa for $S_{t-1}^{+}$). $v_{t}^{2}=u_{t}^{2} / h_{t}^{1 / 2}$ where $h_{t}$ is the conditional variance under the null. The sign bias test is the $t$-statistic for testing $H_{0}: b=0$ in (3); the negative size bias test is the $t$-statistic for testing $H_{0}: b=0$ in (4); and the positive size bias test is the $t$-statistic for testing $H_{0}: b=0$ in (5). These tests can also be carried out jointly using the following regression:

$$
v_{t}^{2}=a+b_{1} S_{t-1}^{-}+b_{2} S_{t-1}^{-} u_{t-1}+b_{3} S_{t-1}^{+} u_{t-1}+e_{t}
$$

The LM test of the joint null hypothesis $H_{0}: b_{1}=b_{2}=b_{3}=0$ has a $\chi_{3}^{2}$ distribution. $^{2}$ The results obtained from applying these tests are also reported in Table 2. The results indicate that for both return series, there is evidence in favour of the null of symmetry for the individual as well as the joint tests. Therefore, our choice of multivariate volatility models has

${ }^{2}$ Harris and Sollis (2003, pg 236) provide a more detailed expositions on the sign bias tests. 


\section{SALISU, ISAH ASSANDRI Dynamic Spillovers in Nigeria}

been narrowed down to the symmetric version. Prominent among these models include, but not limited to, the Constant Conditional Correlations (CCC) model of Bollerslev (1990), Baba, Engle, Kraft and Kroner (BEKK) (1990) multivariate GARCH model which is fully described in Engle and Kroner (1995), the Dynamic Conditional Correlations (DCC) of Engle (2002), and the Vector Autoregressive Moving Average GARCH (VARMA-GARCH) model of Ling and McAleer (2003) and further described in Chang et al. (2013). ${ }^{3}$ The CCC and the VARMA-GARCH models assume constant conditional correlations; hence, the VARMAGARCH models are considered a special case of the CCC model. ${ }^{4} \mathrm{We}$ further test for the validity of the CCC assumption using the Engle and Sheppard (2001) test with the null hypothesis of constant correlation against the alternative of dynamic conditional correlation. Thus, the rejection of the null may imply adoption of DCC model while the non-rejection favours the CCC and its variants such as the VARMA-GARCH models. The result of the test as reported in Table 3 does not seem to reject the null hypothesis of preference for the CCC model $[p$-value $=0.072] .{ }^{5}$ Therefore, it may be more appropriate to estimate with the CCC variants than the DCC. In addition, unlike the VECH and BEKK, the CCC models do not suffer from the curse of dimensionality (see McAcleer, 2005; McAleer et al., 2008; Caporin and McAleer, 2009, 2010; and Chang et al., 2013). Dean et al. (2010) also highlight two main limitations of the BEKK model: (i) It lacks parameter parsimony and (ii) Interpretation of its parameters is complicated by its quadratic form. In the section that follows, we describe our choice of CCC variant for the spillover analysis.

Table 3: Some formal pre-tests for Stock and Money Market Returns

\begin{tabular}{|l|c|c|}
\hline Statistics & $\begin{array}{c}\text { Stock } \\
\text { market }\end{array}$ & $\begin{array}{c}\text { Money } \\
\text { market }\end{array}$ \\
\hline \hline Sign bias test & 0.608 & 1.28 \\
\hline Negative size bias test & 0.331 & 0.562 \\
\hline Positive size bias test & 0.928 & 0.311 \\
\hline Joint bias test & 1.086 & 3.565 \\
\hline Engle-Sheppard CCC $\chi 2$ test & 5.268 & \\
\hline
\end{tabular}

\footnotetext{
${ }^{3}$ Also note that these multivariate models have their respective asymmetric versions that account for asymmetry effects. They are not discussed here because of the preliminary results indicating that the sign bias (which captures asymmetry effect) is not significant as to influence the outcome of the spillover analysis.

${ }^{4}$ A review of all the multivariate volatility models is provided in Silvennoinen and Terasvirta (2008).

${ }^{5}$ Although it marginally rejects at $10 \%$; however, the CCC variants offer more superior empirical attractions (see Caporin and McAcleer, 2009, 2010 for a detailed critique of DCC and BEKK).
} 


\section{The Model}

The underlying theory for the analysis of spillover transmission between two financial markets hinges on the Modern Portfolio Theory (MPT) developed by Markowitz (1952). The MPT has remained one of the most important and influential finance theories explaining how investors can design an optimal portfolio to maximize returns by taking on a quantifiable amount of risk. Thus, the MPT provides the bedrock for diversifying portfolios by investors/financial managers. The theory assumes that by combining assets that are not perfectly correlated, the risks embedded in a portfolio are lowered and higher risk-adjusted returns can be achieved. In other words, while one asset class is confronted with high uncertainty over a particular period of time, the other may not and therefore, a combination of these asset classes, for example, may reduce overall investment risk and prevent damaging a portfolio's performance by the underperforming asset. Further, by investing in more than one stock, an investor can reap the benefits of diversification - chief among them, a reduction in the riskiness of the portfolio. Thus, an effective combination of these asset classes will necessarily require rigorous analysis of any possible spillovers between the assets. ${ }^{6}$ This is the main objective of the study. We attempt to analyse how the potential of risks associated with Nigerian stock and money markets to serve as diversifiable risks where such risks can be mitigated or eliminated by adding the affected assets to a diversified investment portfolio.

As we have emphasized earlier, the underlying econometric model adopted in this study is the one that captures the inherent features of the selected financial assets. Based on our preliminary analyses in the previous section, the CCC variants ranging from the traditional CCC to VARMA-GARCH variants are favoured. We however favour the use of the VARMA-GARCH model over the conventional CCC for the following reasons. ${ }^{7}$ First, it allows us to investigate the conditional volatility dynamics of the series as well as the conditional interdependence cross effects and volatility transmission between series (Arouri et al., 2011). Although, the conditional correlations can be estimated in practice, the CCC model does not permit any interdependencies of volatilities across different assets and/or markets, and does not accommodate asymmetric behaviour (Chang et al., 2013). Second, it also provides meaningful estimates of the parameters with less computational complication compared to several other multivariate specifications such as the full factor GARCH model (Hammoudeh et al., 2009; and Arouri et al., 2011a,b). This approach has increasingly gained prominence in the literature. For example, it has been applied by, among others, Chan et al.

6 Some of the discussions underpinning MPT can be retrieved from https://www.investopedia.com/managing-wealth/modern-portfolio-theory-why-its-stillhip/

7 The computational advantages of the VARMA-GARCH model are well documented in Ling and McAleer (2003), McAleer et al. (2010) and Arouri et al. (2011). 


\section{SALISU, ISAH ASSANDRI Dynamic Spillovers in Nigeria}

(2005), and Hammoudeh et al. (2009) to analyze tourism demand variations and stock markets, Agren (2006), Arouri et al. (2011) and Salisu and Oloko (2015a) to oil price and stock markets, Salisu and Mobolaji (2013) to oil price and exchange rate and Salisu and Oloko (2015b) to analyse the relationship between foreign exchange and stock markets.

The generalized framework for the VARMA-GARCH model is described in the following specifications (see Chang et al., 2013: pg 121):

The Conditional Mean Equation (VARMA):

$$
\begin{gathered}
\Phi(L)\left(Y_{t}-\mu\right)=\Psi(L) \varepsilon_{t} \\
\varepsilon_{t}=D_{t} \eta_{t}
\end{gathered}
$$

The Conditional Variance Equation:

$$
H_{t}=W+\sum_{l=1}^{r} A_{l} \varepsilon_{t-l}^{2}+\sum_{l=1}^{s} B_{l} H_{t-l}
$$

where $Y_{t}=\left(y_{1 t}, \ldots, y_{m t}\right)^{\prime}$ denotes $m \times 1$ vector of return series; $\mu=\left(\mu_{1}, \ldots, \mu_{m}\right)^{\prime}$ is a vector of constants for the mean equations of the return series; $\Phi(L)=I_{m}-\Phi_{1} L-\cdots \Phi_{1} L^{p}$ and $\Psi(L)=I_{m}-\Phi_{1} L-\cdots \Phi_{1} L^{q}$ are polynomials in the lag operator $(L) ; D_{t}=\operatorname{diag}\left(h_{i, t}^{1 / 2}\right)$ for $i=1, \ldots, m ; \eta_{t}=\left(\eta_{1 t}, \ldots, \eta_{m t}\right)$ is a sequence of independently and identically distributed random vectors; $H_{t}=\left(h_{1 t}, \ldots, h_{m t}\right)^{\prime}, \quad \varepsilon^{2}=\left(\varepsilon_{1 t}^{2}, \ldots, \varepsilon_{m t}^{2}\right)^{\prime}$. Note also that $h_{i, t}^{1 / 2}$ and $h_{i, t}$ are conditional standard deviation and conditional variance for return $i, m$ is the number of returns, $W$ is a vector of constants for the variance equations of the return series and $A_{t}$ for $l=1, \ldots, r$ and $B$ for $l=1, \ldots, s$ are $m \times m$ matrices and represent the ARCH and GARCH effects, respectively. The conditional variance equation for each return in the portfolio captures the spillover effects between money and stock. As we are concerned with two return series, a bivariate VARMA $(1,1)$-GARCH $(1,1)$ model is estimated. ${ }^{8}$ The conditional mean and conditional variance equations for the latter model are given as:

\section{A: The Conditional Mean [VARMA (1,1)]:}

$$
Y_{t}=\mu+\Phi_{1} Y_{t-1}+\Psi_{1} \varepsilon_{t-1}+\varepsilon_{t}
$$

\footnotetext{
${ }^{8}$ Of course, the usual way is to consider different lag combinations and then use the SIC or AIC to determine the optimal lag length. However, given that the model gets more complicated as the number of lags increases, a more plausible option is to start small and thereafter test for remaining serial correlation. Thus, higher orders are considered only if necessary.
} 
where $Y_{t}=\left(y_{1 t}, y_{2 t}\right)^{\prime}$ denotes the return series for stock (with subscript 1) and money (with subscript 2) respectively; $\mu=\left(\mu_{1}, \mu_{2}\right)^{\prime}$ is a vector of constants for stock and money respectively; $\Phi=\left(\begin{array}{ll}\phi_{11} & \phi_{12} \\ \phi_{21} & \phi_{22}\end{array}\right) \quad$ is a $(2 \times 2)$ matrix of coefficients on the lagged terms of the return series and it captures return spillovers; $\Psi=\left(\begin{array}{ll}\psi_{11} & \psi_{12} \\ \psi_{21} & \psi_{22}\end{array}\right)$ is a $(2 \times 2)$ matrix of coefficients on the lagged terms of the residuals and $\varepsilon_{t}=\left(\begin{array}{lll}\varepsilon_{1 t} & \varepsilon_{2 t}\end{array}\right)^{\prime}$ is a vector of disturbance terms for mean equations of stock and money. These parameters are defined this way since there are two financial markets being analysed and therefore we can describe equation (10) as a bivariate $\operatorname{VARMA}(1,1)$ model. ${ }^{9}$ The return spillovers are better appreciated using the individual mean equations below:

$$
\begin{gathered}
y_{1 t}=\mu_{1}+\phi_{11} y_{1 t-1}+\phi_{12} y_{2 t-1}+\psi_{11} \varepsilon_{1 t-1}+\psi_{12} \varepsilon_{2 t-1}+\varepsilon_{1 t} \\
y_{2 t}=\mu_{2}+\phi_{21} y_{1 t-1}+\phi_{22} y_{2 t-1}+\psi_{21} \varepsilon_{1 t-1}+\psi_{22} \varepsilon_{2 t-1}+\varepsilon_{2 t}
\end{gathered}
$$

Equations (11) and (12) are the respective mean equations for stock $\left(y_{1 t}\right)$ and money $\left(y_{2 t}\right)$ market returns. The return spillover from money to stock is measured by $\phi_{12}$ (see (11)) while from stock to money is $\phi_{21}$ (see (12)).

\section{B: The Conditional Variance Equation [GARCH $(1,1)]$ :}

$$
H_{t}=W+A \varepsilon_{t-1}^{2}+B H_{t-1}
$$

where $H_{t}=\left(\begin{array}{ll}h_{1 t} & h_{2 t}\end{array}\right)^{\prime}, \varepsilon_{t}^{2}=\left(\begin{array}{ll}\varepsilon_{1 t}^{2} & \varepsilon_{2 t}^{2}\end{array}\right)^{\prime}$, and $W, A$ and $B$ are $(2 \times 2)$ matrices of constants, ARCH effects and GARCH effects respectively. Equation (13) can be further simplified into individual conditional variance equations for the two return series as described below (see Arouri et al., 2011):

\footnotetext{
${ }^{9}$ This approach has also been used in the literature to evaluate spillover transmission between two financial markets. Examples include but not limited to Arouri and Nguyen (2010), Arouri, Jouini and Nguyen (2011a, 2011b, 2012), Salisu and Mobolaji (2013), Salisu and Oloko (2015), Tule et al. (2017, 2018).
} 
SALISU, ISAH ASSANDRI Dynamic Spillovers in Nigeria

$$
\begin{aligned}
& h_{1 t}=c_{1}+\alpha_{11} \varepsilon_{1 t-1}^{2}+\alpha_{12} \varepsilon_{2 t-1}^{2}+\beta_{11} h_{1 t-1}+\beta_{12} h_{2 t-1} \\
& h_{2 t}=c_{2}+\alpha_{21} \varepsilon_{1 t-1}^{2}+\alpha_{22} \varepsilon_{2 t-1}^{2}+\beta_{21} h_{1 t-1}+\beta_{22} h_{2 t-1}
\end{aligned}
$$

The shock spillover effects seem more evident in equations (14) and (15). For example, the conditional variance of the stock returns (as in (14)) depends not only on its own past conditional variance and shocks, but also on those of the money market returns. The same explanation holds for the conditional variance of the money market returns. More specifically, the shock spillover effects from money to stock are captured by the parameters $\alpha_{12}$ (see (14)) while $\alpha_{21}$ measures the shock spillover effects from stock to money. Thus, the transmission of shocks from one market to another is easily quantified using the VARMA-GARCH model.

In terms of estimation technique, the quasi-maximum likelihood estimator (QMLE) is used to estimate the model parameters. The QMLE involves maximizing the likelihood function given as (see Ling and McAleer, 2003):

$$
L_{n}(\lambda)=\frac{1}{n} \sum_{t=1}^{n} l_{t}(\lambda), l_{t}(\lambda)=\frac{1}{2} \ln \left|D_{t} \Gamma D_{t}\right|-\frac{1}{2} \varepsilon_{t}^{\prime}\left(D_{t} \Gamma D_{t}\right)^{-1} \varepsilon_{t}
$$

where $L_{n}(\lambda)$ takes the form of the Gaussian log-likelihood; $\lambda$ denotes the vector of parameters to be estimated and $D_{t} \Gamma D_{t}=\varepsilon_{t} \varepsilon_{t}^{\prime}=D_{t} \eta_{t} \eta_{t}^{\prime} D_{t}$. One of the attractions to the QMLE is the fact that $\eta_{t}$ is assumed to be non-normal which is a prominent feature of most financial series including those under consideration in this paper. Thus, when $\eta_{t}$ does not follow a joint multivariate normal distribution, the appropriate estimator is the QMLE. ${ }^{10}$

\section{C: Computation of Long Run and Short Run Persistence of Shocks to Returns:}

Generally (using equation (9)), the short run persistence or ARCH effect of shocks to return $i$ is denoted by $\sum_{l=1}^{r} \alpha_{i l}$ while $\sum_{j=1}^{r} \alpha_{i j}+\sum_{j=1}^{s} \beta_{i j}$ represents the long run persistence of shocks to return $i$ (see Chang et al., 2013). Note that $\sum_{l=1}^{s} \beta_{i l}$ denotes the GARCH effect. In relation to our specific model and using a simplified representation; the long run persistence to stock

10 The asymptotic properties of the VARMA-GARCH models are well detailed in Ling and McAleer (2003). 
market is represented by $\alpha_{11}+\beta_{11}$. In a similar fashion, $\alpha_{22}+\beta_{22}$ denotes the long run persistence of shocks to money. These two sources of shocks persistence are also evaluated in this paper.

\section{Diagnostics for VARMA-GARCH Models}

Like other multivariate volatility models, the two prominent post-estimation diagnostic tests for the VARMA-GARCH models are the Ljung-Box test for serial correlation and McLeodLi tests for ARCH effects. Both tests are performed on the standardized residuals which have been previously defined as $\hat{\varepsilon}_{i, t}=\hat{\eta}_{i, t} \hat{H}_{t}^{-1 / 2}$. The former test has the null hypothesis of no serial correlation while the latter tests the null of no ARCH effects. For the chosen VARMAGARCH model to be valid, we are not expected to reject the null hypotheses for the two tests. A rejection of the null for the Ljung-Box test may imply inadequacy of the dynamics captured in the mean equation of the model. Thus, one way of resolving this is to increase the lags of the $\mathrm{AR}$ and MA terms in the mean equation and thereafter use the model selection criteria such as the Schwartz Bayesian Criterion (SBC) and Akaike Information Criterion (AIC) to determine the optimal lag length. However, a rejection of the null for the McLeod-Li tests is an indication that variance equation of the model is not properly specified. In other words, some ARCH effects are still present even after estimation. To resolve this problem, it may be necessary to consider other plausible types of the multivariate GARCH models such as the DCC and BEKK rather than increasing the ARCH and GARCH terms. In any case, it is rare to increase the $\mathrm{ARCH}$ and $\mathrm{GARCH}$ terms to fix the variance equation. In this study, we consider both tests to confirm the appropriateness of the estimated model for the analysis of the spillover effect between stock and money.

\section{Results}

The results of the VARMA(1,1)-CCC-GARCH are presented in table 3. We also estimate models with higher orders [VARMA(1,2)-CCC-GARCH, VARMA(2,1)-CCC-GARCH and $\operatorname{VARMA}(2,2)-\mathrm{CCC}-\mathrm{GARCH}]$ and thereafter compare their performance with our model using the standard model selection criteria (i.e. SIC, AIC and Hannan-Quin). ${ }^{11}$ The results are presented in Table 5. As depicted in the table, the VARMA(1,1)-CCC-GARCH appears to give the best fit among the competing models based on the information criteria. Our interpretation of the VARMA(1,1)-CCC-GARCH results essentially focuses on three issues:

11 We used Regression Analysis Time Series version 8.0 (i.e., RATS 8.0) for the estimation of our multivariate GARCH model. Relative to some of the alternative softwares for the estimation of MGARCH, the RATS software has a special feature that allows for the simultaneous analyses of both returns and volatility spillovers between or among markets. 


\section{SALISU, ISAH ASSANDRI Dynamic Spillovers in Nigeria}

return spillovers, shock spillovers and shock persistence (both short run and long run). Before we proceed, let us evaluate the post-estimation diagnostics in order to further check the desirability of the chosen model.

Table 4: VARMA-CCC-GARCH Results

\begin{tabular}{|c|c|c|c|}
\hline Variables & Stock & Variables & Money \\
\hline \multicolumn{4}{|c|}{ Mean Equation } \\
\hline$\mu_{1}$ & $\begin{array}{l}-0.0374 \\
(0.0000)^{\mathrm{a}}\end{array}$ & $\mu_{2}$ & $\begin{array}{l}-0.0098 \\
(0.0000)^{\mathrm{a}}\end{array}$ \\
\hline$\phi_{11}$ & $\begin{array}{l}0.0530 \\
(0.0000)^{\mathrm{a}}\end{array}$ & $\phi_{22}$ & $\begin{array}{l}0.9860 \\
(0.0000)^{\mathrm{a}}\end{array}$ \\
\hline$\phi_{12}$ & $\begin{array}{l}0.0927 \\
(0.0000)^{\mathrm{a}}\end{array}$ & $\phi_{21}$ & $\begin{array}{l}-0.0043 \\
(0.0003)^{\mathrm{a}}\end{array}$ \\
\hline$\psi_{11}$ & $\begin{array}{l}0.0243 \\
(0.0005)^{\mathrm{a}}\end{array}$ & $\psi_{22}$ & $\begin{array}{l}-0.0207 \\
(0.0000)^{\mathrm{a}}\end{array}$ \\
\hline$\psi_{12}$ & $\begin{array}{l}0.0541 \\
(0.0005)^{a}\end{array}$ & $\psi_{21}$ & $\begin{array}{l}0.2772 \\
(0.0000)^{\mathrm{a}}\end{array}$ \\
\hline
\end{tabular}

Variance Equation

\begin{tabular}{|l|l|l|l|}
\hline$C_{1}$ & $\begin{array}{l}9.3295 \\
(0.0020)^{\mathrm{a}}\end{array}$ & $c_{2}$ & $\begin{array}{l}0.5296 \\
(0.0000)^{\mathrm{a}}\end{array}$ \\
\hline$\alpha_{11}$ & $\begin{array}{l}0.2331 \\
(0.0000)^{\mathrm{a}}\end{array}$ & $\alpha_{22}$ & $\begin{array}{l}0.2082 \\
(0.0000)^{\mathrm{a}}\end{array}$ \\
\hline$\alpha_{12}$ & $\begin{array}{l}0.0135 \\
(0.0049)^{\mathrm{a}}\end{array}$ & $\alpha_{21}$ & $\begin{array}{l}0.0302 \\
(0.0005)^{\mathrm{a}}\end{array}$ \\
\hline$\beta_{11}$ & $\begin{array}{l}0.6101 \\
(0.0000)^{\mathrm{a}}\end{array}$ & $\beta_{22}$ & $\begin{array}{l}0.2771 \\
(0.0000)^{\mathrm{a}}\end{array}$ \\
\hline$\beta_{12}$ & $\begin{array}{l}0.0632 \\
(0.0014)^{\mathrm{a}}\end{array}$ & $\beta_{21}$ & $\begin{array}{l}-0.0227 \\
(0.0005)^{\mathrm{a}}\end{array}$ \\
\hline $\begin{array}{l}\text { Long run } \\
\text { shock } \\
\text { Persistence }\end{array}$ & 0.8432 & $\begin{array}{l}\text { Long run } \\
\text { shock } \\
\text { Persistence }\end{array}$ & 0.4853 \\
\hline $\begin{array}{l}\text { CCC } \\
\text { between } \\
\text { stock \& } \\
\text { money }\end{array}$ & $\begin{array}{l}-0.1092 \\
(0.0000)^{\mathrm{a}}\end{array}$ & & \\
\hline
\end{tabular}

Note: ${ }^{a}$ denotes Statistical significance at $5 \%$ level.

\subsection{Diagnostics}

The results of the diagnostic tests are presented in Table 6 . We observe from the diagnostics that there are no remaining ARCH effects after the estimation judging by the McLeod-Li tests both at 5 and 10 lags. In the case of Ljung-Box tests, there is no evidence of serial correlation at different lags for stock while the null of serial independence is rejected for the money 
market returns. However, the Multivariate (joint) Ljung-Box indicates evidence of serial independence in the estimated multivariate model. Overall, the results seem plausible and therefore form the basis for the estimation of spillover effects between the stock and money market returns.

\subsection{Return Spillovers}

The parameters of interest here are $\phi_{12}$ and $\phi_{21}$. As noted earlier, the former measures return spillover from money to stock while the latter captures return spillover from stock to money. Nonetheless, we include own lagged returns in the conditional mean equations to ensure that spillover effects are not confounded with serial dependence (see Dean et al., 2010). As observed in Table 4, $\phi_{12}$ is estimated as 0.0927 and it is statistically significant and positively signed. This indicates that a $1 \%$ increase in money market returns will increase stock returns the following month by approximately $0.09 \%$ on average, ceteris paribus. Expectedly, at some level, it may make sense to assume that an increase in the rate of growth of money supply occasioned by an increase in the demand for money may strengthen the rate of increase in stock prices. In other words, the rate of change in stock prices is expected to increase if it is preceded by an increase in the rate of change of money supply. Conversely however, we find $\phi_{21}$ to be negative and statistically significant. The coefficient is given as 0.0043 implying that the money market returns will reduce by $0.0043 \%$ the following month should the stock returns increase by $1 \%$. This finding supports the substitution effect where an increase in stock returns creates an incentive for increased investments in stocks as a substitute for money. Intuitively, the spillover effect from money to stock is stronger than from stock to money in absolute value. Digging further, we find that returns to both markets are significantly affected by their past realizations and therefore accounting for them when forecasting the returns may enhance their forecast performance.

\subsection{Shock Spillovers and Persistence of Shocks}

In the case of shock spillovers and persistence of shocks, the parameters of interest are the ARCH $\left(\alpha_{i j}\right)$ and GARCH $\left(\beta_{i j}\right)$ terms $[i, j=1,2]$ and all of them are statistically significant. Specifically, lagged own shocks $\left(\alpha_{i i}\right)$ and lagged own conditional variance $\left(\beta_{i i}\right)[\forall i=1,2]$ significantly and positively influence the volatilities of the two markets. In essence, the volatilities of stock returns and money market returns are sensitive to both past own shocks as well as past own conditional variance. In clear terms, volatilities in these two markets may be accentuated by their own shocks. These findings have far reaching implications. First, unanticipated events in the stock market in the current period, for example, are capable of fuelling a high volatility in the market in the immediate succeeding 


\section{SALISU, ISAH ASSANDRI Dynamic Spillovers in Nigeria}

period. Secondly, volatility of the market in one period has the potential of driving a higher volatility in the immediate later period. Thirdly, technically speaking, the past own innovation and past own conditional variance of the two returns can be employed to forecast their future volatility.

Similarly, we find evidence for significant shock spillovers between the two markets. Considering the shock spillovers and looking at the stock market returns, the result shows that a $1 \%$ increase in the shocks to money market returns in the current month will increase the volatility of stock market returns by $0.01 \%$ in the following month. However, the shock spillover from stock returns to money market returns seems higher (although marginally) as a $1 \%$ increase in the shock to stock returns in the current period is likely to increase the volatility of money market returns by $0.03 \%$ in the following month. Nonetheless, the crossmarket shock spillovers are both positive and statistically significant. In other words, there is possibility of contagion effect between the two markets.

In terms of persistence of shocks, we find that stock returns appear to experience higher long run shock persistence than the money market returns. The magnitude of the long run persistence of shocks to stock returns is very close to 1 (0.8432) implying that shocks have persistent effects on stock returns in different ways. In other words, volatility in the stock market exhibits weak mean reversion. However, the long run persistence of shocks to money market returns is fairly small $(0.4853)$; therefore, the shocks are likely to die out over time; and thus, are not permanent.

In the case of short run persistence of shocks, the magnitudes for both stock and money market returns ( 0.2466 and 0.2384 respectively) are quite small. Thus, a more distinct shock which is anticipated in the short run does not have persistent effects on the returns of the two markets in the short run. Lastly, the constant conditional correlation coefficient is constant and statistically significant; thus, validating the assumption of constant correlations between the two markets.

In sum, the following features are discernible from the analyses:

1 Overall, the Nigerian stock market is more sensitive to shocks than its money market judging by both the long run and short run persistence of shocks. This further reinforces the descriptive statistics (standard deviation to be precise) showing that stock market is more volatile than money market. This is understandable given the increasing magnitude of foreign investment portfolio investments in the Nigerian stock exchange.

2 Also, there is a significant contagion effect between the stock market and money market in Nigeria. In other words, a shock to one market (say stock market) is more likely to spill over to the other market (i.e. money market); thus, fuelling a higher volatility in the latter market. 
3 We also find evidence of both wealth and substitution effects in the Nigerian financial markets. However, further analyses of the transmission mechanism for these effects by future research would uncover the supposed complex interactions between the stock and money markets.

\subsection{Robustness Checks}

\subsubsection{Are the size and direction of the spillovers sensitive to variable measurements?}

The literature is replete with evidence suggesting the important role of inflation in the valuation of assets (see for a review, Swaray and Salisu, 2018; Salisu et al., 2019). To this end, we extend the analyses to capture the role of inflation by expressing the relevant variables in real terms and replicating the previous analyses for same. The results are presented in Table 7 and a cursory look at the results still indicates the spill-over effects from money to stock as relatively stronger in absolute term when compared to spill-over effects from stock to money. More so, the sign and significance of the coefficients are largely the same irrespective of whether the return series are expressed in nominal or real form. What this portends is that our finding and choice of volatility model are not sensitive to variable measurements.

\subsubsection{Are the size and direction of the spillovers sensitive to macroeconomic conditions?}

We also evaluate the robustness of the empirical results to macroeconomic conditions by controlling for exchange rate and oil price shocks. To achieve this, we extend the variance equation component of the volatility model to accommodate these factors as exogenous regressors and the results are presented in Table 8. Recall that in the main estimation (see Table 4), we considered the persistence of shocks to the markets, particularly in the long run situation but mainly within the system. As observed in Table 8, we still find little or no difference in the degree of persistence of the shocks even when we account for exogenous regressors in the system. Thus, it can be deduced that our finding and choice of volatility model are equally robust to macroeconomic conditions. For instance, the persistence of shocks in the markets is mainly due to own innovation with little or no influence to shocks due to external factors. We may assume that the potential influence of such macroeconomic conditions is already absorbed by the inherent shocks in the series and therefore analysing the impact of same on volatility may not yield any significant result. 
SALISU, ISAH ASSANDRI Dynamic Spillovers in Nigeria

Table 7: VARMA-CCC-GARCH Results with return series expressed in real term

\begin{tabular}{|l|l|l|l|}
\hline Variables & Stock & Variables & Money \\
\hline \multicolumn{5}{|c|}{ Mean Equation } \\
\hline$\mu_{1}$ & $\begin{array}{l}0.3305 \\
(0.0000)^{\mathrm{a}}\end{array}$ & $\mu_{2}$ & $\begin{array}{l}-0.1785 \\
(0.0000)^{\mathrm{a}}\end{array}$ \\
\hline$\phi_{11}$ & 0.1872 & $\phi_{22}$ & 0.9282 \\
& $(0.0000)^{\mathrm{a}}$ & & $(0.0000)^{\mathrm{a}}$ \\
\hline$\phi_{12}$ & -0.0240 & $\phi_{21}$ & -0.0222 \\
& $(0.5421)$ & $(0.0000)^{\mathrm{a}}$ \\
\hline$\psi_{11}$ & 0.0285 & $\psi_{22}$ & -0.0119 \\
& $(0.0000)^{\mathrm{a}}$ & & $(0.0000)^{\mathrm{a}}$ \\
\hline$\psi_{12}$ & 0.0098 & $\psi_{21}$ & 0.0235 \\
& $(0.0000)^{\mathrm{a}}$ & & $(0.0000)^{\mathrm{a}}$ \\
\hline
\end{tabular}

Variance Equation

\begin{tabular}{|l|l|l|l|}
\hline$C_{1}$ & $\begin{array}{l}16.3228 \\
(0.0000)^{\mathrm{a}}\end{array}$ & $c_{2}$ & $\begin{array}{l}-0.0091 \\
(0.0000)^{\mathrm{a}}\end{array}$ \\
\hline$\alpha_{11}$ & $\begin{array}{l}0.1677 \\
(0.0000)^{\mathrm{a}}\end{array}$ & $\alpha_{22}$ & $\begin{array}{l}0.0444 \\
(0.0000)^{\mathrm{a}}\end{array}$ \\
\hline$\alpha_{12}$ & $\begin{array}{l}0.6407 \\
(0.0000)^{\mathrm{a}}\end{array}$ & $\alpha_{21}$ & $\begin{array}{l}0.1442 \\
(0.0000)^{\mathrm{a}}\end{array}$ \\
\hline$\beta_{11}$ & $\begin{array}{l}0.7047 \\
(0.0000)^{\mathrm{a}}\end{array}$ & $\beta_{22}$ & $\begin{array}{l}-0.3649 \\
(0.0000)^{\mathrm{a}}\end{array}$ \\
\hline$\beta_{12}$ & $\begin{array}{l}11.0438 \\
(0.0000)^{\mathrm{a}}\end{array}$ & $\beta_{21}$ & $\begin{array}{l}0.7838 \\
(0.0000)^{\mathrm{a}}\end{array}$ \\
\hline $\begin{array}{l}\text { Long run shock } \\
\text { Persistence }\end{array}$ & 0.8724 & $\begin{array}{l}\text { Long run shock } \\
\text { Persistence }\end{array}$ & 0.4093 \\
\hline $\begin{array}{c}\text { CCC between } \\
\text { stock \& money }\end{array}$ & $\begin{array}{l}-0.0560 \\
(0.0000)^{\mathrm{a}}\end{array}$ & \multicolumn{3}{|l}{} \\
\hline
\end{tabular}

Diagnostics (Post-Estimation)

\begin{tabular}{|l|c|c|}
\hline Statistics & Stock & Money \\
\hline LB (5) & 1.4283 & 4.4020 \\
\hline LB (10) & 6.5079 & 4.6153 \\
\hline McLeod-Li (5) & 0.5080 & 0.0217 \\
\hline McLeod-Li (10) & 6.2665 & 0.3458 \\
\hline
\end{tabular}

Note: ${ }^{a}$ denotes Statistical significance at $5 \%$ level. 
Review of Economic Analysis 11 (2019) 255-283

Table 8: VARMA-CCC-GARCH Results with exogenous regressors

\begin{tabular}{|c|c|c|c|}
\hline Variables & Stock & Variables & Money \\
\hline \multicolumn{4}{|c|}{ Mean Equation } \\
\hline$\mu_{1}$ & $\begin{array}{l}0.7701 \\
(0.0000)^{\mathrm{a}}\end{array}$ & $\mu_{2}$ & $\begin{array}{l}0.1202 \\
(0.0000)^{a}\end{array}$ \\
\hline$\phi_{11}$ & $\begin{array}{l}0.1394 \\
(0.0000)^{\mathrm{a}}\end{array}$ & $\phi_{22}$ & $\begin{array}{l}0.9512 \\
(0.0000)^{a}\end{array}$ \\
\hline$\phi_{12}$ & $\begin{array}{l}0.3215 \\
(0.0000)^{a}\end{array}$ & $\phi_{21}$ & $\begin{array}{l}-0.0012 \\
(0.0000)^{a}\end{array}$ \\
\hline$\psi_{11}$ & $\begin{array}{l}0.0295 \\
(0.0000)^{\mathrm{a}}\end{array}$ & $\psi_{22}$ & $\begin{array}{l}0.0561 \\
(0.0000)^{\mathrm{a}} \\
\end{array}$ \\
\hline$\psi_{12}$ & $\begin{array}{l}0.0176 \\
(0.0000)^{\mathrm{a}} \\
\end{array}$ & $\psi_{21}$ & $\begin{array}{l}0.0310 \\
(0.0000)^{\mathrm{a}}\end{array}$ \\
\hline \multicolumn{4}{|c|}{ Variance Equation } \\
\hline$C_{1}$ & $\begin{array}{l}8.2288 \\
(0.0000)^{\mathrm{a}}\end{array}$ & $C_{2}$ & $\begin{array}{l}0.4732 \\
(0.0000)^{\mathrm{a}}\end{array}$ \\
\hline$\alpha_{11}$ & $\begin{array}{l}0.2115 \\
(0.0000)^{a}\end{array}$ & $\alpha_{22}$ & $\begin{array}{l}0.1874 \\
(0.0000)^{a}\end{array}$ \\
\hline$\alpha_{12}$ & $\begin{array}{l}1.3369 \\
(0.0700)\end{array}$ & $\alpha_{21}$ & $\begin{array}{l}0.0003 \\
(0.0097)^{a}\end{array}$ \\
\hline$\beta_{11}$ & $\begin{array}{l}0.6665 \\
(0.0000)^{\mathrm{a}}\end{array}$ & $\beta_{22}$ & $\begin{array}{l}-0.0253 \\
(0.0000)^{a} \\
\end{array}$ \\
\hline$\beta_{12}$ & $\begin{array}{l}-8.4102 \\
(0.0000)^{a}\end{array}$ & $\beta_{21}$ & $\begin{array}{l}-0.3905 \\
(0.0000)^{\mathrm{a}}\end{array}$ \\
\hline Exchange rates & $\begin{array}{l}0.1814 \\
(0.0000)^{\mathrm{a}}\end{array}$ & Exchange rates & $\begin{array}{l}-0.1035 \\
(0.0000)^{\mathrm{a}}\end{array}$ \\
\hline Oil prices & $\begin{array}{l}0.2293 \\
(0.0000)^{a}\end{array}$ & Oil prices & $\begin{array}{l}0.0199 \\
(0.0000)\end{array}$ \\
\hline $\begin{array}{l}\text { Long run shock } \\
\text { Persistence }\end{array}$ & 0.8780 & $\begin{array}{l}\text { Long run shock } \\
\text { Persistence }\end{array}$ & 0.2127 \\
\hline $\begin{array}{l}\text { CCC between } \\
\text { stock \& money }\end{array}$ & $\begin{array}{l}0.0333 \\
(0.0000)^{\mathrm{a}} \\
\end{array}$ & & \\
\hline \multicolumn{4}{|c|}{$\begin{array}{c}\text { Diagnostics (Post-Estimation) } \\
\end{array}$} \\
\hline \multicolumn{2}{|c|}{ Stock } & \multicolumn{2}{|c|}{ Money } \\
\hline LB (5) & 1.0496 & \multicolumn{2}{|c|}{$11.4441^{\mathrm{a}}$} \\
\hline LB (10) & 4.5011 & \multicolumn{2}{|c|}{$20.3424^{\mathrm{a}}$} \\
\hline $\begin{array}{l}\text { McLeod- } \\
\text { Li (5) }\end{array}$ & 0.7880 & \multicolumn{2}{|c|}{3.8869} \\
\hline $\begin{array}{l}\text { McLeod- } \\
\text { Li (10) }\end{array}$ & 5.9998 & \multicolumn{2}{|c|}{$11.7955^{\mathrm{a}}$} \\
\hline
\end{tabular}

Note: ${ }^{a}$ denotes Statistical significance at $5 \%$ level. 


\section{SALISU, ISAH ASSANDRI Dynamic Spillovers in Nigeria}

\subsubsection{Are the size and direction of spillovers sensitive to the choice of estimation technique?}

\subsubsection{Spillover table}

In addition to the VARMA-MGARCH approach adopted in this study, we also explore the variance decomposition method based on Diebold and Yilmaz (2012) to further subject our findings to robustness check using the ij entry known as spillover table. The spillover table as demonstrated in Table 9 indicates the estimates for the contribution to $i^{\text {th }}$ market's forecasterror variance generated by shocks to market $j$. The diagonal elements of the tables $(j=i)$ are the own variance shares estimates, which show the portion of the forecast-error variance of market $i$ that is due to its own innovations.

Summing up the off diagonal row elements of Table 9 for example, we estimate the spillover effects received by stock market from money market (column: Directional spillovers from other markets), while the sum of the off diagonal column elements produce the spillover effects directed from stock market to money market or all other markets (row: Directional spillovers to other markets).

Table 9: Diebold and Yilmaz (2012) spillover table

\begin{tabular}{|l|l|l|l|}
\multicolumn{2}{|c|}{ Return spillovers } \\
& Stock Market & $\begin{array}{l}\text { Money } \\
\text { Market }\end{array}$ & $\begin{array}{l}\text { Directional Spillovers } \\
\text { from other Markets }\end{array}$ \\
\hline Stock Market & 97.40 & 2.60 & 3.00 \\
\hline Money Market & 1.80 & 98.20 & 2.00 \\
\hline $\begin{array}{l}\text { Directional Spillovers } \\
\text { to other Markets }\end{array}$ & 2.00 & 3.00 & \multirow{2}{*}{$\begin{array}{l}\text { Total Spillover Index } \\
\text { (5.0/195.20=) } 2.56 \%\end{array}$} \\
\hline Directional including own & 99.20 & 101.00 & \\
\hline Net Spillovers & 96.20 & 99.00 & \\
\hline
\end{tabular}

Volatility spillovers

\begin{tabular}{|c|c|c|c|}
\hline & Stock Market & $\begin{array}{l}\text { Money } \\
\text { Market }\end{array}$ & $\begin{array}{l}\text { Directional Spillovers } \\
\text { from other Markets }\end{array}$ \\
\hline Stock Market & 99.90 & 0.10 & 0.00 \\
\hline Money Market & 0.40 & 99.60 & 0.00 \\
\hline $\begin{array}{l}\text { Directional Spillovers } \\
\text { to other Markets }\end{array}$ & 0.00 & 4.80 & \multirow{3}{*}{$\begin{array}{l}\text { Total Spillover Index } \\
(0.00 / 200=) 0.00 \%\end{array}$} \\
\hline Directional including own & 100.00 & 100.00 & \\
\hline Net Spillovers & 100.00 & 100.00 & \\
\hline
\end{tabular}


The net spillover effects from stock market to money market are calculated by subtracting "directional spillovers from" from "directional spillovers to". The approximate total spillover index in percentage points is calculated as the grand sum of the off-diagonal elements of the table divided by the grand sum of all elements in the table.

Starting with the return spillovers, the empirical estimates in Table 9 show that the total spillovers index is $2.56 \%$. This though implies there is low level of interconnectedness between the stock and money markets; however, the examination of the gross directional return spillovers tends to support our earlier findings. Reflecting this is the directional returns spillover result which is $3 \%$ and $2 \%$ from money market to stock market and from stock market to money market respectively. What this portends is that nonetheless the choice of estimation technique, the money market is likely to exert greater impact on stock market. Strengthening this fact is the Net spillover result which reveals money market with $99 \%$ net spillovers as highest net transmitter of shocks relative to stock market net spillovers of $96 \%$. From the volatility perspective however, the variance decomposition based on the Diebold and Yilmaz method tends to attribute all the volatilities in the respective market to own innovations in each market.

\subsubsection{Rolling sample analysis}

As a form of robustness for the spillovers presented in Table 9, we further examine the timevarying feature of the spillover indices using the rolling sample framework. This approach also helps us to trace some crisis episodes that may be responsible for the observed spillover transmission between the two markets. The analyses are presented in graphical form (see Figures 2 and 3 for return and volatility spillovers respectively). Both figures seem to suggest presence of time-varying spillovers. Precisely, both the total return and volatility spillovers were lower during the period of global financial crisis (2008-2010) than the later period. In other words, the interconnectedness between the two markets improves after the global financial crisis with the exception of mid-2013. This seems to imply that the global financial crisis weakened the relationship between the stock and money markets in Nigeria.

Note that the Figures 2 and 3 are for total return and volatility spillovers respectively. It is also possible to evaluate the dynamic behaviour for the "directional spillovers from" and "directional spillovers to". The following figures therefore, are dynamic ways of representing the row and column estimates in Table 9, but in a manner that is parallel to the earlier discused total spillover plots. The information as earlier demonstrated is contained in the "Directional TO others" (row) and the "Direction FROM others". 


\section{SALISU, ISAH ASSANDRI Dynamic Spillovers in Nigeria}

In Figure 4, we present the directional return spillovers from money market to stock market and -from stock market to money market (corresponding to the "directional spillovers to others" in Table 9.) Confirming our earlier position, the return spillover from money market to stock market seems generally higher than that of stock market to money market, particularly after the global financial crisis (the period of 2010 to 2013). Similarly, the conclusion drawn from Figure 5 for the scenario involving "directional spillovers from others" largely remains the same where money market again appears to exert greater influence. Also, Figures 6 and 7 present the directional volatility spillovers plots. The former is for "directional volatility spillover to" and vice versa for the latter. Again, volatility spillover from money market to stock market seems relatively higher when compared to the magnitude of volatility spillovers from stock market to money market. On the whole, investors or investment analysts may find it optimal to combine the two financial assets given the low contagion effects between them.

Figure 2: Return spillovers

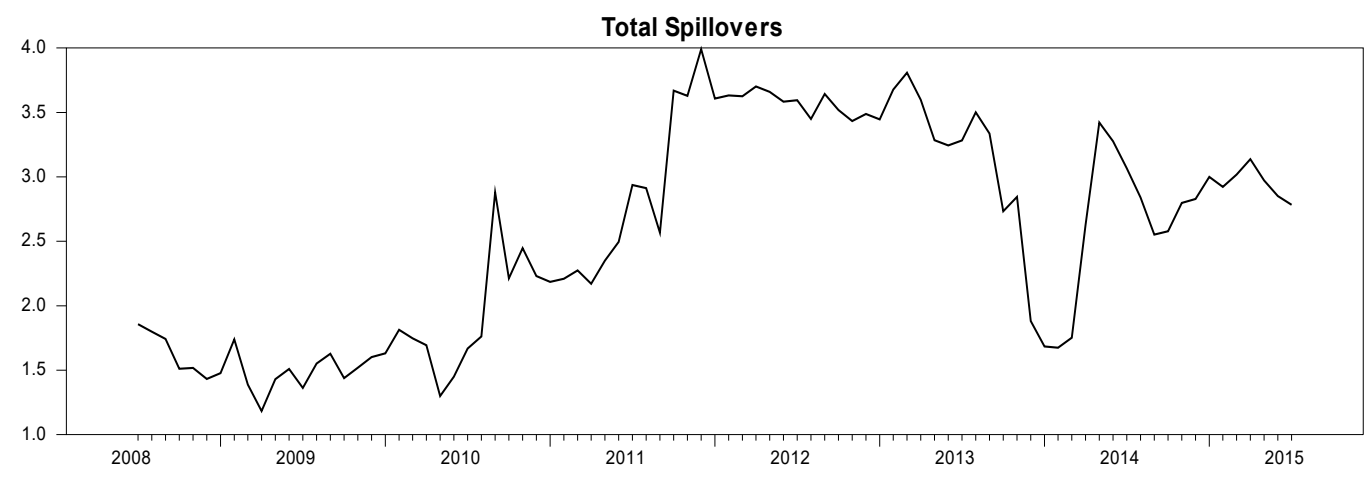

Figure 3: Volatility spillovers

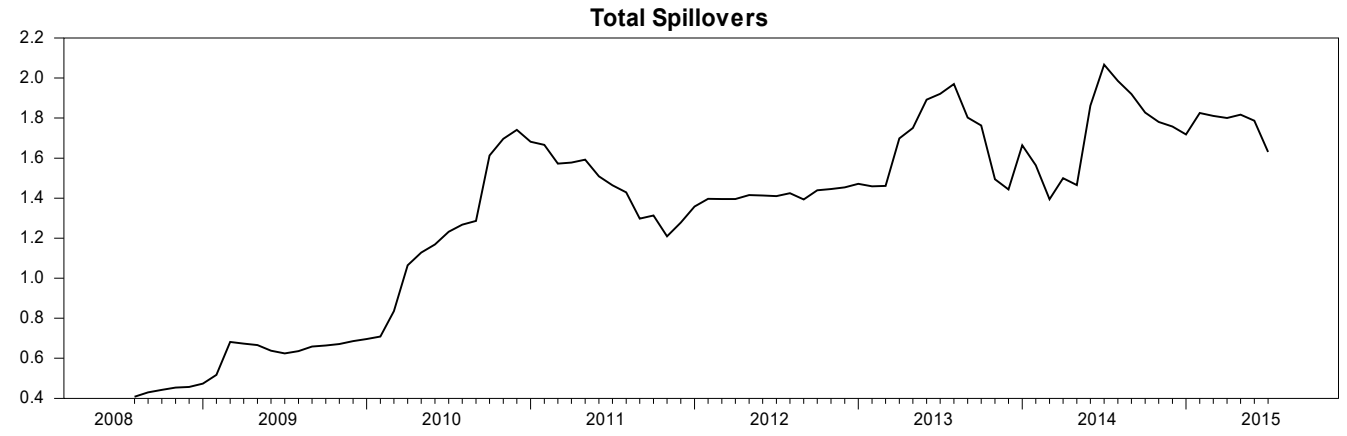


Review of Economic Analysis 11 (2019) 255-283

Figure 4: Gross return spillover plots (Directional spillovers to other markets)
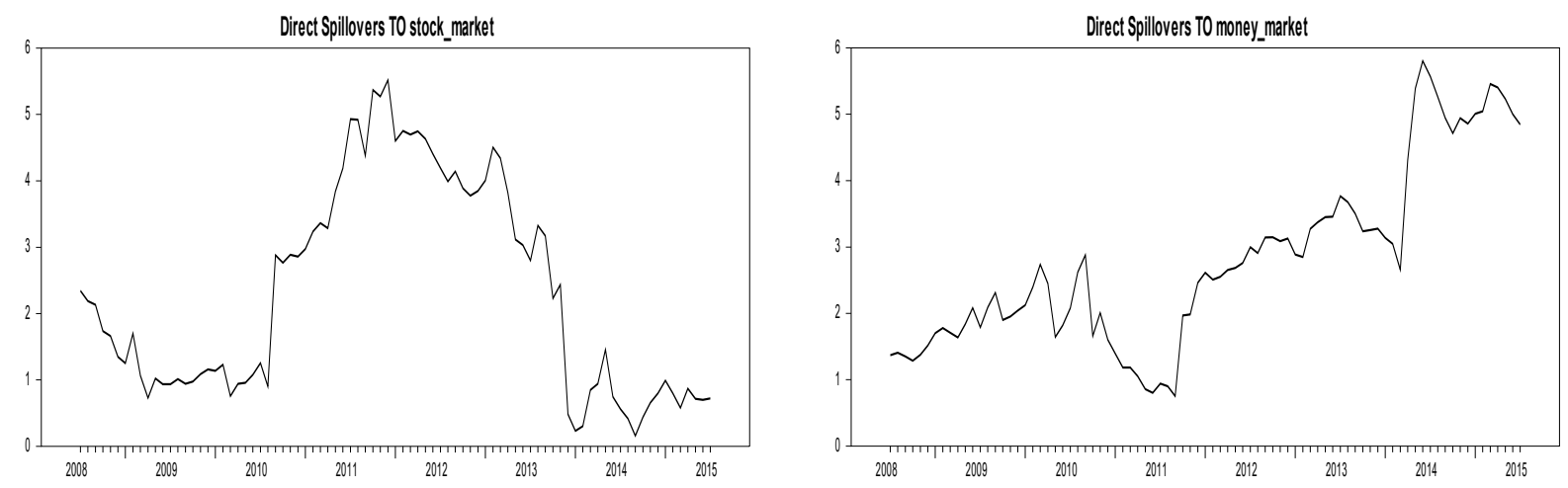

Figure 5: Gross return spillover plots (Directional spillovers from other markets)
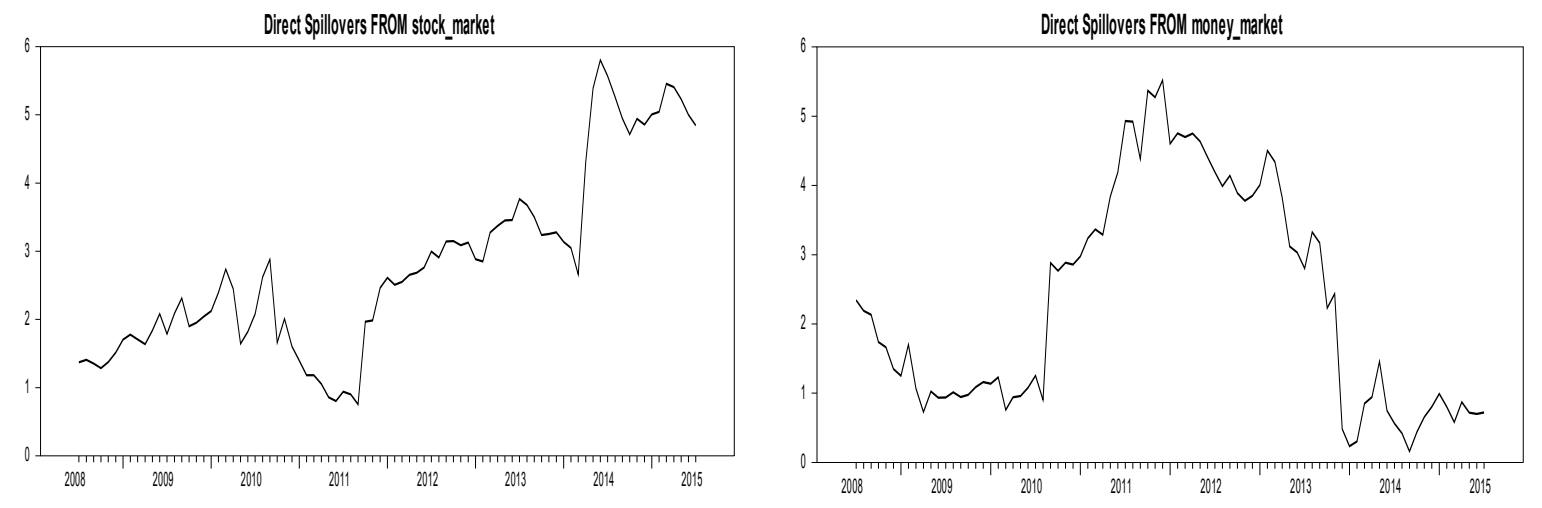

Figure 6: Gross volatility spillover plots (Directional spillovers to other markets)
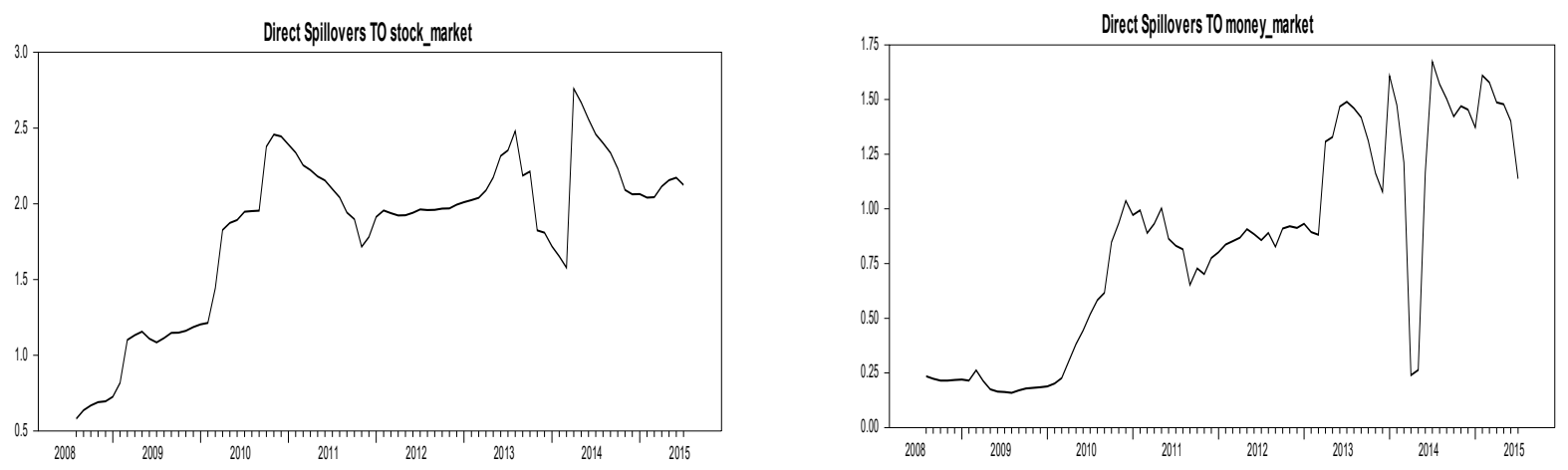


\section{SALISU, ISAH ASSANDRI Dynamic Spillovers in Nigeria}

Figure 7: Gross volatility spillover plots (Directional spillovers from other markets)
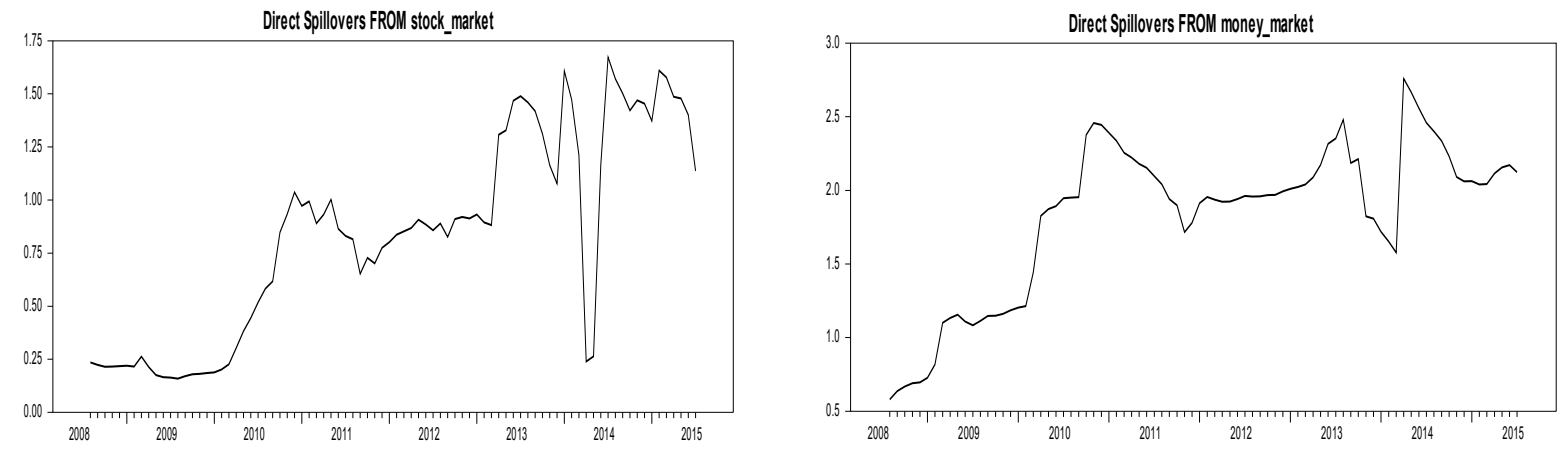

\section{Conclusions}

The goal of this paper was to examine the extent of return and shock spillovers between stock market and money market using monthly data for the period January 2000 to July 2015. To model the spillovers, we used the VARMA-CCC-GARCH model after careful considerations of relevant tests and model selection criteria, but further complement it with the variance decomposition method developed by Diebold and Yilmaz (2012). Our main findings are as follows.

First, stock market is more volatile than money market in Nigeria. Second, shocks to stock returns tend to persist when they occur while shocks to money market returns tend to die out over time. There are two implications of these findings: (i) these findings imply that the behaviour of stock market returns tends to change over time while that of the money market appears fairly stable; and (ii) it then follows that investors need to consider this nature of stock market behaviour when making investment decisions.

Third, we find significant cross-market return and shock spillovers between the two markets although the stock market volatility seems more sensitive to money market volatility than it is from the former to the latter. In addition, the stock market is more susceptible to external shocks than the money market.

Finally, we consider a number of robustness checks and show that our findings are robust to different measures of the return series (i.e. nominal and real value), market conditions and alternative estimation technique. On the whole, it may be necessary to include the past realizations of both returns and volatilities when forecasting their future values in order to enhance forecast performance. 


\section{References}

Agren, M. (2006). Does oil price uncertainty transmit to stock market? Working Paper No. 23. Uppsala University.

Antonakakis, N. and Vergos, K. (2013). Sovereign bond yield spillovers in the Euro zone during the financial and debt crisis. Journal of International Financial Markets, Institutions and Money 26, 258-272.

Arouri, M., Jouin, J. and Nguyen, D. (2011a). Oil prices and sector stock returns: Implication for portfolio management. International Journal of Money and Finance, 30, 1387-1405.

Arouri, M., Lahiani, A., and Nguyen, D. (2011b). Return and volatility transmission between world oil prices and stock markets of the GCC countries. Economic Modelling, 28, 18151825.

Arouri, M. and Nguyen, D. (2010). Oil prices, stock markets and portfolio investment: evidence from sector analysis in Europe over the last decade. Energy Policy 38, 45284539.

Arouri, M., Jouini, J. and Nguyen, D. (2012). On the impacts of oil price fluctuations on European equitymarkets: volatility spillover and hedging effectiveness. Energy Economics. 34, 611-617.

Baba, Y., Engle, R.F., Kraft, D.F. and Kroner, K.F. (1990). Multivariate simultaneous generalized ARCH. Mimeo, University of California at San Diego, department of Economics.

Bollerslev, T. (1990). Modelling the coherence in short-run nominal exchange rates: Multivariate Generalized ARCH Approach. Review of Economics and Statistics, 72, 498505.

Booth, G.G., Martikainen, T. and Tse, Y. (1997). Price and volatility spillovers in Scandinavian stock markets. Journal of Banking and Finance, 21, 811-823.

Browne, F. and Cronin, D. (2010). Commodity prices, money and inflation. Journal of Economics and Business 62, 331-345.

Browne, F. and Cronin, D. (2012). The new dynamic between US stock prices and money holdings. World Economics 13, 137-156.

Caporin, M. and McAleer, M. (2009). Do we really need both BEKK and DCC? A tale of two covariance models. Available at SSRN: $\underline{\text { http://ssrn.com/abstract=1338190. }}$.

Caporin, M. and McAleer, M. (2010). Do we really need both BEKK and DCC? A tale of two multivariate GARCH models. To appear in Journal of Economic Surveys. Available at SSRN: http://ssrn.com/abstract=1549167.

Cenedese, G. and Mallucci, M. (2015). What moves international stock and bond markets? Journal of International Money and Finance, Article in Press.

Chan, F., Lim, C., and McAleer, M. (2005). Modelling multivariate international tourism demand and volatility. Tourism Management 26, 459-471. 


\section{SALISU, ISAH ASSANDRI Dynamic Spillovers in Nigeria}

Chang C., McAleer M. and Tansuchat R. (2013). Conditional correlations and volatility spillovers between crude oil and stock index returns. North American Journal of Economics and Finance, 25, 116-138.

Claeys, P. and Vašicek, B. (2014). Measuring bilateral spillover and testing contagion on sovereign bond markets in Europe. Journal of Banking and Finance 46, 151-165.

Cronin, D. (2014). The Interaction between money and asset markets: A spillover index approach. Journal of Macroeconomics, 39, 185-202.

Dean, W.G., Faff, R. W. and Loudon, G.F. (2010). Asymmetry in return and volatility

spillover between equity and bond markets in Australia. Pacific-Basin Finance Journal, 18, $272-289$.

Diebold, F. X. and Yilmaz, K. (2009). Measuring financial asset return and volatility spillovers, with application to global equity markets. Economic Journal, 119, 158-171.

Diebold, F.X., and Yilmaz, K. (2012). Better to give than to receive: Predictive directional measurement of volatility spillovers. International Journal of Forecasting, 23, 57-66.

Duncan, A. S. and Kabundi, A. (2013). Domestic and foreign sources of volatility spillover to South African asset classes. Economic Modelling 31, 566-573.

Engle, R. (1982). Autoregressive conditional heteroscedasticity with estimates of the variance of the U.K. Inflation. Econometrica, 50, 987-1008.

Engle, R.F. and K.F. Kroner (1995). Multivariate simultaneous generalized ARCH. Econometric Theory, 11, 122-150.

Engle, R. and Ng, V. (1993). Measuring and testing the impact of news on volatility. Journal of Finance, 48, 1749-1777.

Engle, R.F. and Sheppard, K. (2001), Theoretical and empirical properties of dynamic conditional correlation multivariate GARCH. NBER Working Paper.

Fernández-Rodríguez, F., Gómez-Puig, M. and Sosvilla-Rivero, S. (2015). Volatility spillovers in EMU sovereign bond markets. Research Institute of Applied Economics Working Paper 1/32.

Fleming, J., Kirby, C. and Ostdiek, B. (1998). Information and volatility linkages in the stock, bond, and money markets. Journal of Financial Economics, 49, 111-137.

Fowowe, B. and Shuaibu, M. (2016). Dynamic spillovers between Nigerian, South African and international equity markets. International Economics, 148, 59-80.

Friedman, M. (1988). Money and the stock market. Journal of Political Economy, 96(2), 221245.

Giovannetti, G. and Velucchi, M. (2013). A spillover analysis of shocks from US, UK and China on African financial markets. Review of Development Finance, 3, 169-179.

Hammoudeh, S.M., Yuan, Y. and McAleer, M. (2009). Shock and volatility spillovers among equity sectors of the Gulf Arab stock markets. The Quarterly Review of Economics and Finance 49, 829-842. 
Harris, R. And Sollis, R. (2003). Applied time series modelling and forecasting (2nd ed). London, John Wiley and Sons.

Kal, S.H., Arslaner, F. and Arslaner, N. (2015). The dynamic relationship between stock, bond and foreign exchange markets. Economic Systems, Article in Press, 1-27.

Kambouroudis, D.S. (2016). Modeling and Forecasting Stock Market Volatility in Frontier Markets: Evidence from Four European and Four African Frontier Markets. Handbook of Frontier Markets, the European and African Evidence, 39-54.

Kang, S.H., Mclver, R. and Yoon, S. (2017). Dynamic spillover effects among crude oil, precious metal, and agricultural commodity futures markets. Energy Economics, 62, 1932.

Kang, S.H. and Yoon, S. (2017). Dynamic spillovers between Shanghai and London nonferrous metal futures markets. Finance Research Letters, 19, 181-188.

Kanga, S.H., Cheong, C. and Yoon, S. (2013). Intraday volatility spillovers between spot and futures indices: Evidence from the Korean stock market. Physica A, 392, 1795-1802.

Karmakar, M. (2010). Information transmission between small and large stocks in the national stock exchange in India: An empirical study. The Quarterly Review of Economics and Finance, 50, 110-120.

Kim, S.W. and Rogers, J.H. (1994). International stock price spillovers and market liberalization: Evidence from Korea, Japan, and the United States. Journal of Empirical Finance, 2, 117-133.

King, D. and Botha, F. (2015). Modelling stock return volatility dynamics in selected African markets. Economic Modelling, 45, 50-73.

Koutmos, G. and Booth, G.G. (1995). Asymmetric volatility transmission in international stock markets. Journal of International Money and Finance, 14(6), 747-762.

Kuttu, S. (2014). Return and volatility dynamics among four African equity markets: A multivariate VAR-EGARCH analysis. Global Finance Journal, 25(1), 56-69.

Kuttu, S. (2017). Modelling long memory in volatility in sub-Saharan African equity markets. Research in International Business and Finance, DOI: https://doi.org/10.1016/j.ribaf.2017.07.073.

Liow, K.H. (2015). Volatility spillover dynamics and relationship across G7 financial markets. North American Journal of Economics and Finance, 33, 328-365.

Markowitz, H.M. (1952). Portfolio Selection. The Journal of Finance. 7 (1): 77-91.

McAleer, M. (2003), Automated inference and learning in modelling financial volatility, Econometric Theory, 21, 232-261.

McAleer, M.F. Chan, S., Hoti and Lieberman, O. (2008). Generalized autoregressive conditional correlation. Econometric Theory, 24, 1554-1583.

Nelson, D. B. (1991). Conditional heteroskedasticity in asset returns: A new approach. Econometrica, 59, 347-370. 


\section{SALISU, ISAH ASSANDRI Dynamic Spillovers in Nigeria}

Nguyen, T. and Nguyen, C. (2014). Analyzing dependence structure of equity, bond and money markets by using time-varying copulas. International Journal of Economics and Finance, 6(3).

Oberholzer, N. and Boetticher, S.T. (2015). Volatility Spill-over between the JSE/FTSE Indices and the South African Rand. Procedia Economics and Finance, 24, 501-510.

Raimony, A. and El-Nader, H. (2012): The sources of stock market volatility in Jordan. International Journal of Economics and Finance, 4(11).

Salisu, A.A. and Mobolaji, H. (2013). Modelling returns and volatility transmission between oil price and US-Nigeria exchange rate. Energy Economics, 39, 169-176.

Salisu, A.A. and Oloko, T. (2015a). Modelling oil price-US stock nexus: A VARMA-BEKKAGARCH approach. Energy Economics, Elsevier, 50(C), 1-12.

Salisu, A.A. and Oloko, T. (2015b). Modelling spillovers between stock market and FX market: evidence for Nigeria. Journal of African Business, 16(1-2), 84-108.

Salisu, A. A. \& Swaray, Raymond \& Oloko, Tirimisiyu F., 2019. "Improving the predictability of the oil-US stock nexus: The role of macroeconomic variables," Economic Modelling, Elsevier, vol. 76(C), pages 153-171.

Skintzi, V.D. and Refenes, A.N. (2006). Volatility spillovers and dynamic correlation in European bond markets. Journal of International Financial Markets, Institutions and Money, 16, 23-40.

Steeley, J.M. (2006). Volatility transmission between stock and bond markets. Journal of International Financial Markets, Institution and Money, 16, 71-86.

Sugimoto, K., Matsuki, T. and Yoshida, Y. (2014). The global financial crisis: An analysis of the spillover effects on African stock markets. Emerging Markets Review 21, 2 01-233.

Swaray, Raymond \& Salisu, Afees A., 2018. "A firm-level analysis of the upstreamdownstream dichotomy in the oil-stock nexus," Global Finance Journal, Elsevier, vol. 37(C), pages 199-218.

Tule, Moses K. \& Ndako, Umar B. \& Onipede, Samuel F., 2017. Oil price shocks and volatility spillovers in the Nigerian sovereign bond market. Review of Financial Economics, Elsevier, vol. 35(C), pages 57-65.

Tule, Moses \& Dogo, Mela \& Uzonwanne, Godfrey, 2018. Volatility of stock market returns and the naira exchange rate. Global Finance Journal, Elsevier, vol. 35(C), pages 97-105.

Wahyudi, I, and Sani, G. (2013). Interdependence between Islamic capital market and money market: Evidence from Indonesia. Borsa Istanbul Review, 14, 32-47.

Weber, E. (2013). Simultaneous stochastic volatility transmission across American equity markets. The Quarterly Review of Economics and Finance, 53, 53-60.

Zhang, J., Zhang, D., Wang, J. and Zhang, Y. (2013). Volatility spillovers between equity and bond markets: Evidence from G7 and BRICS. Romanian Journal of Economic Forecasting, 16(4), 205-217. 